\title{
BAHASA SUNDA DAN PENGGUNAANNYA DALAM INTERAKSI JUAL BELI DI PASAR SINDANG KABUPATEN CIREBON
}

\begin{abstract}
Afi Fadlilah ${ }^{1}$
Abstract

One dialect of Cirebon language is dialect Jawareh. It is the Java language which mix with Sundanese used in South of Cirebon regency, especially in Sindang Market on Lemahabang districts. This paper will discuss the language use in Sindang Market because it has its own characteristics that are different from the others Sundanese in West Java. This is because it is influenced by the geographical location and the diversity of backgrounds of the speech community. Based on this, this paper will discuss the Sundanese language and its use in the buying and selling interaction on the sindang market of Cirebon with the aim to describe the structure of the language and how to use it. The method used in this paper is the observational method with taping and recording techniques of the speech event data that is analyzed descriptively qualitative by using linguistic theory. The results of this study is that the specific characteristics of Sundanese in buying and selling interaction in the sindang market contained in intonation and the removal of vowel phonemes / a / and / / on specific vocabulary.
\end{abstract}

Keywords: Sundanese, Sundanese structure, the Use of Sundanese, Characteristics, and Linguistics.

\section{Pendahuluan}

Bahasa Sunda adalah bahasa yang digunakan oleh sebagian masyarakat tutur di wilayah Jawa Barat, khususnya di Kabupaten Cirebon meskipun masyarakat setempat menyebut dengan bahasa Cirebon. Bahasa Cirebon memiliki empat dialek, yaitu dialek Plered, dialek Gegesik, dialek Plumbon, dan dialek Jawareh. Dialek Jawareh inilah yang digunakan oleh sebagian masyarakat tutur di Kabupaten Cirebon bagian selatan tarutama di Pasar Sindang Kecamatan Lemahabang. Istilah Jawareh merupakan singkatan dari Jawa sawareh, yaitu bahasa Jawa (selanjutnya disingkat BJ) sebagian bahasa Sunda (selanjutnya disingkat BS). Di pasar ini penjual (selanjutnya disingkat PN) dan pembeli (selanjutnya disingkat PM) menggunakan bahasa Cirebon dialek Jawareh (selanjutnya disingkat BCDJ) dan bahasa Indonesia (selanjutnya disingkat BI) meskipun ada juga yang menggunakan salah satu bahasa

\footnotetext{
${ }^{1}$ Staf Pengajar Departemen Pendidikan Bahasa dan Sastra Indonesia FPBS UPI, Bandung. Korespondensi email: afhee_green@yahoo.com
} 
tertentu, misalnya BJ, BS atau pun BI saja. Hal ini karena tidak semua PN dan PM menguasai BJ atau pun BS, sehingga BI dijadikan sebagai lingua franca.

Munculnya BS dalam BCDJ dipengaruhi oleh faktor kultural, yakni budaya Sunda karena keberadaan pasar tersebut yang berbatasan langsung dengan wilayah kultural Sunda, khususnya Sunda Kuningan dan Sunda Majalengka. Sementara itu, adanya pemakaian BI selain karena sebagian mereka tidak menguasai salah satu dari kedua bahasa tersebut, juga karena berasal dari etnis Cina dan Arab. Kedatangan mereka itu sejak masa penyebaran agama Islam di daerah Cirebon pada awal abad ke-14, yang sudah banyak disinggahi oleh para pedagang dari berbagai daerah yang umumnya beragama Islam. Hal ini terbukti dengan adanya pelabuhan Muhara Jati sejak awal abad ke-15 dan pelabuhan Cimanuk pada awal abad ke-16. Para pedagang tersebut antara lain berasal dari Parsi, Arab, Pasai, India, Palembang, Malaka, Tumasik, Cina, Jawa, dan Madura sebagaiamana yang digambarkan oleh Ekajati dalam Naskah Purwaka Caruban Nagari (PCN) (1974: 31).

Lebih lanjut Tom Pires menjelaskan dalam Kisah Perjalanannya, bahwa di pelabuhan Cimanuk yang masih dikuasai kerajaan Sunda banyak di antara penduduknya beragama Islam (A. Cortesao 1944: 173). Menurut Tom Pires, selain pelabuhan Cimanuk, pelabuhan lain di daerah Cirebon adalah pelabuhan Cerimon/Choroboam (Cirebon), sebuah pelabuhan yang bagus dan banyak perahu yang berlabuh sampai tiga atau empat buah setiap waktu. Salah satu perahu itu adalah Lancaran (sejenis perahu yang lajunya sangat cepat) yang dapat menghulu sungai mengalir sampai kira-kira $15 \mathrm{~km}$. Pelabuhan yang berpenduduk lebih dari 1.000 orang itu memperdagangkan beras dan berbagai jenis makanan, sedangkan kayu untuk membuat perahu merupakan jenis kayu terbaik di Pulau Jawa yang berasal dari daerah itu (Kys: 183). Pelabuhan lain ialah pelabuhan Japura, terletak antara Cirebon dan Losari yang berpenduduk sekitar 2.000 orang dan tersebar di berbagai dusun, terutama di dusun Lemahabang lokasi Pasar Sindang berada.

Selain faktor sejarah, BS dalam interaksi jual beli di Pasar Sindang juga dipengeruhi oleh faktor lokasi. Letak Pasar Sindang cukup strategis karena berada di alun-alun Kecamatan Lemahabang dan di sisi jalan raya menuju Kota Cirebon yang berjarak sekitar $17 \mathrm{~km}$. Letak pasar yang strategis mempermudah akses bagi warga dari daerah sekitar untuk berbelanja. Selain itu, pasar tersebut merupakan pusat perbelanjaan yang cukup lengkap, ramai, dan lebih besar jika dibandingkan dengan pasar-pasar lain di sekitarnya. Kemajemukan suku, bahasa dan bangsa masyarakat tutur di Pasar Sindang membawa akibat semakin bervariasinya kode-kode yang dimiliki dan dikuasai oleh PN dan PM. Di antaranya adalah terdapat banyak individu yang memiliki atau menguasai tiga bahasa, yakni 
BJ, BS dan BI yang masing-masing tuturannya mempunyai pola dan fungsi tertentu serta sangat tergantung pada peserta tutur atau relasi tuturnya. Fenomena kebahasaan itulah yang secara linguistik menarik untuk dikaji dalam artikel ini.

Di dalam artikel ini hanya akan mendeskripsikan BS yang digunakan dalam interaksi jual beli di Pasar Sindang dengan tujuan untuk mengetahui ikhwal struktur BSDJ di Kabupaten Cirebon. Pemakaian BS ini cukup unik, terutama dalam intonasi (lentong) dan beberapa leksikon yang berbeda dengan Bahasa Sunda Lulugu (selanjutnya disingkat BSL), yakni bahasa Sunda yang digunakan oleh masyarakat tutur daerah Priangan (Bandung dan sekitarnya). Oleh karena itu, dalam artikel ini akan dideskripsikan mengenai unsur-unsur linguistik BSDJ yang meliputi fonologi, morfologi, dan sintaksis.

\section{Pembahasan}

Secara gramatikal, BS yang digunakan dalam interaksi jual beli di Pasar Sindang Kabupaten Cirebon tidak menunjukkan adanya perbedaan yang signifikan dengan bahasa Sunda yang dipergunakan di daerah Sunda Priangan atau BSL, kecuali pada beberapa kosakata dan intonasi (lentong) tuturannya. Hal tersebut berdasarkan pemerian oleh Abdurachman, dkk. (1985) bahwa, bahasa Sunda Cirebon (selanjutnya disingkat BSC) tidak jauh berbeda dengan BSL dan ciri khasnya dapat dilihat dan dirasakan terutama dalam kosa kata dan lentong (intonasi) tuturannya. Oleh karena itu, penelitian ini hanya akan menyajikan beberapa leksikon atau kosakata bahasa Sunda dalam interaksi jual beli di Pasar Sindang yang tidak dipergunakan di daerah Priangan. Perbedaan kosa kata antara BSDJ dengan BSL dapat dilihat pada tabel 1

Tabel 1. Perbedaan Leksikon BSDJ dengan BSL

\begin{tabular}{|l|l|l|}
\hline \multicolumn{2}{|c|}{ BSDJ } & \multicolumn{1}{c|}{ BSL } \\
\hline \multicolumn{1}{|c|}{ BAGIAN TUBUH } \\
\hline Capung & Bapang & Tanduk, kumis melintang \\
\hline Hulu hate & Angeun & Ulu hati \\
\hline Pulak (huntu) & Pungklak, lesot & Gigi patah sedikit \\
\hline Apen & Sirit & Alat kelamin laki-laki \\
\hline \multicolumn{2}{|c|}{ KATA GANTI SAPAAN DAN KEKRABATAN } \\
\hline Enok & Nyai & Panggilan untuk anak Pr \\
\hline Otong & Ujang & Panggilan untuk anak Lk \\
\hline Subiang & Indung & Ibu kandung \\
\hline Kita & Urang & Kita \\
\hline
\end{tabular}


Lanjutan tabel 1

\begin{tabular}{|c|c|c|}
\hline Emak kolot & Nini & Nenek \\
\hline Nyaneh & Maneh & Kamu \\
\hline \multicolumn{3}{|c|}{ JALAN, RUMAH DAN PRABOTAN } \\
\hline Gili & Jalan & Jalan \\
\hline Panimbal & Teko leutik tina taneuh & Teko \\
\hline Kenot & Suweng & Giwang (perhiasan) \\
\hline Lading & Peso & Pisau \\
\hline Sosi & Konci & Kunci \\
\hline Sorowal & Celana & Celana \\
\hline Ceret & Saputangan & Saputangan \\
\hline \multicolumn{3}{|c|}{ TUMBUHAN DAN BUAH } \\
\hline Celem & Anageun & Sayur, kuah \\
\hline Keletuk & Jambu batu & Jambu batu \\
\hline Kemaduan & Mangandoh & Benalu \\
\hline Pentil buah & Pakel & Buah muda \\
\hline Sapocong & Satengah geugeus & Dua kepal padi \\
\hline Tabo & Tapas kelapa & Sabut kelapa \\
\hline \multicolumn{3}{|c|}{ AKTIVITAS } \\
\hline Jarag & Jorag/ontrog & Mendatangi \\
\hline Miang & Indit & Pergi \\
\hline MenEng & Cicing & Diam \\
\hline NgubEng & Nguriling & Berputar \\
\hline Sewot & AmbEk & Marah \\
\hline Sepit & Sunatan, nyunatan & Khitanan \\
\hline SlamEtan & salamEtan & Selametan \\
\hline
\end{tabular}

\section{Fonologi}

Sebagaimana dikatakan sebelumnya, bahwa BSDJ tidak berbeda jauh dengan BSL, termasuk dalam hal sistem bunyi. Hal ini ditegaskan oleh Abdurrachman (1985) dalam penelitiannya, bahwa sistem bunyi BSC tidak berbeda dengan BSL. Dikatakan Abdurrachman bahwa untuk membuktikan fonem-fonem vokal dan konsonan dalam BSC, dipergunakan cara pembuktian pasangan minimal, misal, /bata/ dipasangkan dengan /batu/ terbukti pada perbedaan fonem /a/ dan fonem / $\mathrm{u} /$. Berdasarkan data transkripsi rekaman dalam interaksi jual beli di Pasar Sindang, ditemukan bahwa BSDJ memiliki tujuh buah fonem vokal dan delapan belas fonem konsonan yang diuraikan di tabel 2. 
Tabel 2. Fonem Vokal

\begin{tabular}{|c|c|c|c|}
\hline \multirow[t]{2}{*}{ Fonem } & \multicolumn{3}{|c|}{ Posisi } \\
\hline & Awal & Tengah & Akhir \\
\hline 1 & 2 & 3 & 4 \\
\hline [i] & /iang/'pergi' & /siring/ 'sisi' & /gili/ 'jalan' \\
\hline lé/ [ ] & / étém/ 'ketam' & /ngéés/ 'tidur' & /c wénw/ 'perawan' \\
\hline$/ /$ [c] & / ndog/'telur' & /d r p/ 'kuli nuai padi' & \\
\hline$[\mathrm{u}]$ & /uduh/ 'empuk' & /buyut/'ayah kakek' & /kuru/ 'kurus \\
\hline /eu/ [ ] & / w h/'tak ada' & /p j h/ 'hati-hati' & /h nt / 'tidak' \\
\hline /o/ $[\mathrm{o}]$ & /omong/ 'bicara' & /kolot/ 'tua' & /j ro/ 'harga' \\
\hline /a/ $[\mathrm{a}]$ & /aya/ & /nyaah/ & /r ga/ \\
\hline
\end{tabular}

Tabel 3. Fonem Konsonan

\begin{tabular}{|c|c|c|c|}
\hline \multirow[t]{2}{*}{ Fonem } & \multicolumn{3}{|c|}{ Posisi } \\
\hline & Awal & Tengah & Akhir \\
\hline 1 & 2 & 3 & 4 \\
\hline$/ p / \quad[p]$ & $\begin{array}{l}\text { /pam r san/'alat } \\
\text { pemeras' }\end{array}$ & /t mpo/ 'lihat' & $/ \mathrm{k}$ y p/'ketam' \\
\hline$/ \mathrm{b} / \quad[\mathrm{b}]$ & /baskom/'baskom' & /sabaraha/ 'berpa' & /calub/'subur' \\
\hline$/ \mathrm{m} / \quad[\mathrm{m}]$ & /m nang/'dapat' & / mbung/ 'tidak mau' & /c $1 \mathrm{~m} /$ 'sayur' \\
\hline$/ \mathrm{t} / \quad[\mathrm{t}]$ & /tereh/'cepat' & /hati/ 'hati' & /kolot/ 'tua' \\
\hline$/ d / \quad[d]$ & /daek/'mau' & /bade/ 'akan' & /kosod/ 'kosod' \\
\hline$/ \mathrm{n} / \quad[\mathrm{n}]$ & /nuhun/ 'terima kasih' & / ntos/'sudah' & /kulam/'apa' \\
\hline$/ \mathrm{c} / \quad[\mathrm{c}]$ & /calana/'celana' & /boncel/ 'ikan boncel' & \\
\hline$/ \mathrm{j} / \quad[\mathrm{j}]$ & /jero/ 'dalam' & /laja/ 'laos' & \\
\hline /ny/ [ñ ] & /nyaneh/ 'kamu' & /enya/ 'iya' & \\
\hline$/ \mathrm{k} / \quad[\mathrm{k}]$ & /kenging/ 'boleh' & /make/ 'pakai' & /samak/ 'tikar' \\
\hline lg/ $[\mathrm{g}]$ & /goreng/ 'jelek' & /rEga/ 'harga' & /badag/ 'besar' \\
\hline /ng/ [ך] & /ngora/ 'muda' & /ongkoh/ 'lagi pula' & /entong/ 'jangan' \\
\hline$/ \mathrm{s} / \quad[\mathrm{s}]$ & /samping/ 'kain' & /meser/ 'beli' & /wios/ 'tidak apa-apa' \\
\hline$/ \mathrm{h} / \quad[\mathrm{h}]$ & /hanjakal/ 'menyesal' & /muhun/'iya' & /satengah/'setengah' \\
\hline$[1]$ & /laja/ 'laos' & /jalma/'orang' & /moal/ 'tidak akan' \\
\hline$/ \mathrm{r} / \quad[\mathrm{r}]$ & /rea/ 'banyak' & /urang/'orang/kita' & / k r/'sedang' \\
\hline$/ \mathrm{w} / \quad[\mathrm{w}]$ & /wani/ 'berani' & /kuwu/ 'kepala desa' & /c waw/'mulut terbuka' \\
\hline$/ \mathrm{y} / \quad[\mathrm{y}]$ & /yakin/ 'yakin' & /wayah/'waktu' & /jurey/ 'banyak ikan' \\
\hline
\end{tabular}

Selain itu, ditemukan juga adanya ciri khusus berupa penghilangan fonem vokal /a/ pada kata tertentu dalam BS yang berbeda dengan BSL, yakni pada kata sabaraha "berapa". Penutur di Pasar Sindang mengucapkan kata tersebut sabraha, 
ada fonem vokal /a/ yang mengalami pelesapan, yakni pada suku kata kedua, sab-raha yang di dalam BSL diucapkan sa-ba-ra-ha. Jadi, dalam hal ini ada perubahan jumlah suku kata pada kata sabraha, dimana di dalam BSL kata sabaraha terdiri atas empat suku kata, sedangkan dalam BSC terdiri atas tiga suku kata, yaitu kata sabraha.

\section{Morfologi}

Analisis morfologi BSDJ mengacu pada buku Struktur Bahasa Sunda Cirebon Dielaek Cirebon yang ditulis oleh Abdurrachman, dkk. (1985). Pengertian morfologi sebagaimana yang didefinisikan oleh Ramlan (1976:2), yaitu bagian dari ilmu bahasa yang membicarakan atau yang mempelajari seluk beluk struktur kata serta pengaruh perubahan-perubahan struktur kata terhadap golongan dan arti kata. Menurut Abdurrachman (1985: 14), dalam BS ada empat macam proses morfologi, yaitu afiksasi, pengulangan, pemajemukan, dan nasalisasi.

a. Afiksasi adalah proses pembentukan kata dengan penambahan afiks pada kata dasar. Afiks itu selalu berupa morfem terikat dan dapat ditambahkan pada awal kata dalam proses yang disebut prefiksasi, pada akhir kata dalam proses yang disebut sufiksasi, sebagian pada awal kata dan sebagian pada akhir kata dalam proses yang disebut konfikasi, ambifikasi, atau simulfiksasi, atau di dalam kata itu sendiri sebagai suatu "sisipan" dalam proses yang disebut infiksasi. (Verhaar, 1778 : 60). Dalam BS, misalnya, prefiksasi pa- dalam patani 'petani' sufiksasi -keun dalam leutikeun 'kecilkan', simulfiksasi pang-/-na dalam pangpinterna 'terpintar', infiksasi -ar-dalam bentuk barudak 'anak-anak' (jamak).

b. Pengulangan dalam BS ada yang terjadi dengan cara mengulang suku kata pertama, seperti kata sepak 'sepak' terbentuk kata sesepak 'menyepak-nyepak'; dengan cara mengulang seluruh kata, misalnya, sepak-sepak 'sepak-sepak'; dengan cara mengulang seluruh kata yang disertai perubahan pada satu fonem atau lebih dari kata dasar itu, seperti supak-sepak 'sepak-sepak'; tulang-tulang 'tulang-taleng'.

c. Pemajemukan atau komposisi adalah perangkaian bersama-sama dua morfem asal yang menghasilkan satu kata. Seperti telah dibicarakan di atas, kata majemuk terdiri dari dua atau lebih morfem asal - dapat bebas, dapat juga terikat (Verhar, 1978: 64).

d. Nasalisasi adalah perubahan fonem konsonan pada awal kata dengan fonem konsonan nasal yang homorgan, yaitu yang sama dasar ucapannya. Dalam BS, misalnya, pake 'pakai' menjadi make 'memakai', buka 'buka' menjadi muka 'membuka', deuleu 'lihat' menjadi neuleu 'melihat', cacar 'babat' menjadi nyacar 
'membuat (rumput), jait 'angkat' menjadi nyait 'mengangkat', karang 'karang' menjadi ngarang 'mengarang', gegel 'gigit' menjadi ngegel 'menggigit', seuseuh 'cuci' menjadi nyeuseuh 'mencuci'. Nasalisasi pada kata-kata yang dimulai dengan fonem vokal terjadi dengan cara menambahkan fonem /ng/ dan /m/ pada awal kata itu. Dalam BS, misalnya, iang 'pergi' menjadi miang 'berangkat', ngiangkeun 'memberangkatkan'. Emut 'ingat' menjadi ngemut 'mengingat', endog 'telur' menjadi ngendog 'bertelur', asah 'asah' menjadi ngasah 'mengasah', ukur 'ukur' menjadi ngukur 'mengukur', eusi 'isi' menjadi ngeusi 'mengisi', obor 'obor' menjadi ngobor 'mengobor'.

Berdasarkan data peristiwa tutur dalam interaksi jual beli di Pasar Sindang, ditemukan beberapa kata yang mengalami gejala proses morfologi yang berupa, afiksasi meliputi (prefiksasi, sufiksasi, infiksasi dan reduplikasi), nasalisasi dan pengulangan atau reduplikasi. Untuk lebih jelasnya, berikut diuraikan macammacam proses morfologi dalam interaksi jual beli di Pasar Sindang.

\section{Afiksasi}

Proses morfologis yang berupa afiksasi dapat terjadi dari prefiksasi, sufiksasi, dan infiksasi sebagaimana yang terdapat di dalam tabel berikut.

\section{Tabel 4. Afiksasi}

\begin{tabular}{|c|c|c|c|c|}
\hline Prefiks & Reduplikasi & Sufiksasi & Infiksasi & Prefiksasi \\
\hline di- & & & & $\begin{array}{llll}\text { dik } \mathrm{r} \mathrm{t} \\
\text { (tingkatan) }\end{array}$ \\
\hline nga- & $\begin{array}{l}\text { Bo (suku } \\
\text { kata awal) }\end{array}$ & & & $\begin{array}{l}\left.\text { dibobodo 'dibodo-bodo' } \begin{array}{lll}\text { (PT } & 45\end{array}\right) \\
\text { (jamak) }\end{array}$ \\
\hline di- & $\begin{array}{l}\text { na (suku kata } \\
\text { awal) }\end{array}$ & & & dinanaon 'diapa-apa' (PT 43) (jamak) \\
\hline \multirow[t]{5}{*}{ di- } & & -an & & 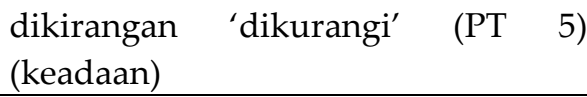 \\
\hline & & -an & & $\begin{array}{l}\text { gambaran 'banyak gambar' (PT 5) } \\
\text { (jamak) }\end{array}$ \\
\hline & & & -ar- & har rin 'pada sesak' (PT 6) (jamak) \\
\hline & & An & -am- & $\begin{array}{l}\text { pam rasan 'alat pemeras' (PT 6) } \\
\text { (kata benda) }\end{array}$ \\
\hline & & $-k n$ & & $\begin{array}{l}\text { hijik n 'persatukan' (PT 6) } \\
\text { (imperatif) }\end{array}$ \\
\hline nga- & & $-k \mathrm{n}$ & & ngalarisk n 'agar laku' (PT 44) (aktif) \\
\hline ma- & & -an & & $\begin{array}{l}\text { mabelasan 'menjadi lima belas' (PT } \\
\text { 47) (aktif) }\end{array}$ \\
\hline
\end{tabular}


Lanjutan tabel 4

\begin{tabular}{|l|l|l|l|l|l|}
\hline & & $-\mathrm{n}$ & & $\begin{array}{l}\text { terang } \mathrm{n} \mathrm{'ketahuan'} \mathrm{(PT} \mathrm{56)} \\
\text { (keadaan) }\end{array}$ \\
\hline di- & & $-\mathrm{k} n$ & & $\begin{array}{l}\text { dikituk n 'dibegitukan' (PT 56) } \\
\text { (aktif) }\end{array}$ \\
\hline pating- & & & -rara- & $\begin{array}{l}\text { pararanjang 'panjang-panjang' (PT } \\
\text { 29) (jamak) }\end{array}$ \\
\hline
\end{tabular}

Semua bentuk afiksasi baik berupa prefiksasi, sufiksasi, simulfiksasi, dan infiksasi dalam BSC terdapat dalam BSL, sebagaimana dalam penelitian Abdurrachman, dkk. (1985). Menurut Abdurrachman, dkk. prefiks yang khusus ditemukan dalam BSC ialah prefiks pak-, namun ini tidak ditemukan dalam data peristiwa tutur dalam jual beli di Pasar Sindang. Semua prefiks dalam BSC bersifat produktif, kecuali prefiks ma- yang tidak produktif.

\section{Nasalisasi}

Nasalisasi adalah proses morfologi dengan cara perubahan fonem konsonan awal kata dengan fonem konsonan nasal yang homorgan, yaitu yang sama dasar ucapannya (Abdurrachman, dkk. 1985). Bentuk kata yang mengalami proses nasalisasi dalam data peristiwa tutur interaksi jual beli di Pasar Sindang, adalah kata ngical (Peristiwa Tutur /PT 23) dan tingali (PT 23). Kata ngical 'menjual' mengalami gejala nasalisasi dengan cara menambahkan fonem /ng/ pada awal kata ical menjadi ngical 'menjual' (aktif). Sementara itu, kata tingali 'melihat' mengalami perubahan fonem konsonan /t/ pada awal kata tingali dengan fonem konsonan nasal yang homorgan, yaitu /n/ sehingga menjadi ningali 'melihat' (aktif). Selain itu, kata ningali juga mengalami gejala afiksasi beupa sufiksasi-i.

\section{Pengulangan}

Proses morfologis yang dasarnya kata tunggal atau morfem dasar bebas adalah proses morfologis yang dilakukan dengan pengulangan atau reduplikasi. Pengulangan itu dapat dengan cara pengulangan suku kata pertama, pengulangan seluruh kata tanpa perubahan fonem pengulangan seluruh kata yang disertai perubahan fonem vokal (Abdurrachman, dkk. 1985). Berdasarkan data peristiwa tutur dalam interaksi jual beli di Pasar Sindang ditemukan beberapa kata yang mengalami proses morfologi berupa pengulangan atau reduplikasi, yaitu kata babaskom (PT 6), bibitingan (PT 6), dan kukumpul (PT 6). Semua kata tersebut 
mengalami gejala pengulangan atau reduplikasi, ada yang hanya pada suku kata pertama saja, seperti babaskom dan kukumpul dan ada yang mengalami pengulangan yang digabungkan dengan afiksasi berupa sufiksasi, seperti kata bibitingan.

Kata baskom mengalami pengulangan pada suku kata awal, yaitu ba menjadi babaskom 'baskom-baskom' (jamak). Begitu juga dengan kata kumpul, yaitu suku kata ku menjadi kukumpul 'kumpul-kumpul' (jamak). Sementara itu, kata bibitingan mengalami proses morfologis berupa pengulangan pada suku kata awal, yaitu $b i$ menjadi bibiting 'lidi-lidi' dan afiksasi berupa sufiksasi -an menjadi bibitingan 'lidilidian' (jamak).

\section{Sintaksis}

Sintaksis adalah salah satu cabang tata bahasa yang membicarakan struktur kalimat, klausa, frase (Tarigan, 1977: 5). Kalimat merupakan tataran setelah morfologi. Berbicara kalimat sebenarnya lebih tepat jika mengulas tentang klausa. Antara kalimat dan klausa ada perbedaan yang mendasar. Menurut Kridalaksana (1984: 83) kalimat adalah (1) satuan bahasa yang secara relatif berdiri sendiri, mempunyai intonasi final dan secara aktual maupun potensial terdiri dari klausa; (2) klausa bebas yang menjadi bagian kognitif percakapan, satuan proposisi yang merupakan gabungan klausa atau merupakan satu klausa, yang membentuk satuan bebas; jawaban minimal seruan, salam dsb; (3) konstruksional gramatikal yang terdiri atas satu atau lebih klausa yang ditata menurut pola yang tertentu, dan dapat berdiri sendiri sebagai satuan.

Jadi, pengertian kalimat menurut Kridalaksana tersebut mengindikasikan bahwa kalimat itu dapat dilisankan dan terdiri dari klausa pembentukannya. Pengertian ini sama dengan pendapat Tarigan (1989: 48) yang mengatakan bahwa kalimat adalah satuan bahasa yang secara relatif dapat berdiri sendiri yang mempunyai pola intonasi akhir yang terdiri dari klausa. Tarigan menyoroti pada aspek intonasi, kemandirian, dan syarat klausa sebagai pembentukannya. Menurut Alwi, dkk. (1998: 311) kalimat adalah satuan bahasa terkecil dalam wujud lisan atau tulis yang mengungkapkan pikiran yang utuh. Berdasarkan pengertian ketiga ahli di atas, dapat disimpulkan bahwa kalimat merupakan satuan bahasa yang terbentuk dari klausa dalam bentuk tulis maupun lisan, dapat berdiri sendiri, dan mengungkap pikiran yang utuh.

Kalimat dalam BSC menurut Abdurrachman, dkk. (1985: 40) mempunyai banyak tipe jika dipandang dari jenis klausanya dan sifat hubungan aktor-aktor aksisnya, antara lain adalah: Subjek Predikat (SP), Subjek Predikat Objek (SPO), 
Subjek Subjek Predikat (SSP), Subjek Predikat Keterangan (SPK), Predikat Objek (PO), Predikat Objek Predikat (POP), Predikat Keterangan Keterangan (PKK), Predikat Objek Keterangan (PKK), Predikat Objek Keterangan (POK), Predikat Keterangan (PK), Subjek Predikat Objek Objek (SPOO), dan Subjek Keterangan Keterangn Predikat (SKKP).

Namun, yang akan diuraikan dalam tulisan ini adalah mengenai struktur kalimat yang dipandang dari segi hubungan aktor aksis, yang dapat dibedakan atas kalimat aktif dan kalimat pasif. Kalimat aktif dan kalimat pasif yang terdapat dalam peristiwa tutur interaksi jual beli di Pasar Sindang akan diuraikan satu persatu sebagai berikut.

\section{Kalimat Aktif}

Kalimat aktif adalah kalimat yang subjeknya berperan sebagai pelaku atau aktor (Abdurrachman, 1985). Ciri-ciri kalimat aktif adalah subjek mengerjakan pekerjaan sebagaimana disebutkan dalam predikat verbal. Predikat verbal ditandai dengan oleh prefiks me-N (meng-), ber, atau tidak ditandai oleh prefiks apapun. Kalimat aktif dalam BSDJ yang terdapat dalam peristiwa tutur interaksi jual beli di Pasar Sindang, antara lain sebagai berikut.

(PT 15) : Kie wis kukumpul durung? (Ini sudah kumpul-kumpul belum?)

(PT 16) : Nya nawarna teu nanaon, nya sok lima rebu. (Ya, menawarkannya tidak apa. Ya, silakan lima ribu).

(PT 20) : : Ari ngical mah dua belas, pedah bae ka Bu Haji. (Kalau menjual sih dua belas, ini karena dengan Bu Haji).

(PT 20) : Embung, geneup, eta ngomong tujuh. (Tidak mau, enam, katanya tujuh).

(PT 43) : : Ayeuna mah nuju usum make lepis. (Sekarang sedang musim memaki levis)

(PT 44) : Dua dua bae tah jeung ngalariskeun keur urang. Urang dua rebu, ngajual mah dua lima bae.

(Dua-dua saja tuh supaya laku saja, untung dua ribu untuk saya, menjualnya dua lima saja).

(PT 27) : Tilu opat ti dituna, ayeuna naek sapuluh teu ngabobodo.

(Tiga emapt dari sananya, sekarang benar-benar naik menjadi sepuluh)

Kalimat-kalimat tersebut tergolong ke dalam kalimat aktif. Kalimat dalam masing-masing PT tersebut predikatnya pada kata kukumpul, nawarna, ngical, ngomong, make, ngalariskeun, dan ngabobodo dengan menggunakan imbuhan $k u$ dan 
ng. Pada kalimat PT 15 predikat berawalan $k u$ dari kata dasar kumpul mendapat prefiks $k u$-; pada kalimat PT 20 predikat berawalan $n g$ dari kata dasar ical mendapat prefiks ng-; predikat pada PT 44 berawalan nga- dan berakhiran - $k$ ön dan dari kata dasar laris; dan predikat pada PT 27 berawalan nga- dan pengulangan pada suku kata pertama bo dari kata dasar bodo menjadi ngabbobodo.

\section{Kalimat Pasif}

Kalimat pasif yaitu kalimat yang subjeknya berperanan sebagai penderita (Abdurrachman, 1985). Sama halnya seperti pendapat Kridalaksana (1990: 112), yang menyatakan bahwa konstruksi pasif akan terjadi bila subjek merupakan sasaran dari perbuatan sebagaimana disebutkan dalam predikat verbal. Verba yang menjadi predikat pada konstruksi pasif biasanya bermarkah prefiks di- dan ter-. Kridalaksana melihat pasif dari sudut subjek sebagai sasaran perbuatan, agen atau pasien tidak begitu dipentingkan. Asal subjek subjek menjadi sasaran perbuatan, kalimat itu disebut pasif. Sementara itu, Alwi, dkk. (1988: 345-349) memberikan ciri-ciri kalimat pasif, yaitu menggunakan verba berprefiks di- dan menggunakan verba tanpa prefiks $d i$-. Kehadiran bentuk oleh pada kalimat pasif bersifat manasuka. Namun, jika verba predikat tidak diikuti langsung oleh pelengkap pelaku (yang sebelumnhya merupakan subjek kalimat aktif), bentuk oleh wajib hadir.

Sementara itu, Ardiwinata (1984: 64) dan Coolsma (1985: 114-119) membagi kalimat pasif BS menjadi dua bentuk, yaitu pasif berawalan di- dan pasif berawalan $k a-$. Pasif yang pertama menunjukkan bahwa seseorang atau sesuatu mengalami sesuatu oleh sebab tertentu, sedangkan pasif yang kedua, seseorang atau sesuatu dibayangkan sebagai pengalaman atau penderita, tetapi bukan sebagai akibat suatu sebab atau keinginan seseorang. Dalam BS, kalimat pasif jenis ini ditandai dengan verba berafiks $d i-, d i-a n$, dan $d i-k e u n$. Hal ini sebagaimana yang terdapat dalam peristiwa tutur interaksi jual beli di Pasar Sindang.

(PT 14) : Ulah ditempo dina gambarna. (Jangan dilihat dari gambarnya)

(PT 34) : :Heu'euh sarebu deui, enam tiga dikembalikeun. (Iya, seribu lagi, enam tiga dikembalikan)

(PT 43) : Biasa nu kumaha? Moal dinanaon ieuh. (Biasa yang bagaimana? Tidak dimahalkan)

(PT 56) : Nya enggeus dibungkus deuh. (Iya sudah dibungkuslah)

Kalimat-kalimat tersebut tergolong ke dalam kalimat pasif. Ciri kalimat pasif itu antara lain ditandai dengan predikatnya yang menggunakan prefiks di-dan di- - 
keun, seperti pada kata ditempo, dikembalikeun, dinanaon dan dibungkus. Pada kalimat PT 14 predikat berawalan di- dari kata dasar tempo; pada kalimat PT 34 predikat berawalan di- dan berakhiran -keun dari kata dasar kembali; predikat pada PT 43 berawalan di- dan pengulangan suku kata pertama na dari kata dasar naon; dan predikat pada PT 56 berawalan di- dari kata dasar bungkus.

\section{Penggunaan Bahasa Sunda}

Penggunaan BS dalam interaksi jual beli di Pasar Sindang Kabupaten Cirebon ada dua macam, yakni penggunaan BS murni dan penggunaan BS Campuran BJ (Jawareh). Penggunaan BS baik murni atau pun campuran dilakukan oleh penjual dan pembeli karena mereka berasal dari etnis yang sama, yaitu etnis Sunda. Berdasarkan daftar penjual di Pasar Sindang, PN yang menempati 384 kios hampir sebagian besar berasal dari etnis Sunda. Sebagian mereka berkomunikasi antar keluarga dan tetangga menggunakan BS murni dalam kehidupan sehari-hari, terutama ketika berada di rumah. Artinya, ketika berkomunikasi menggunakan BS tidak ada campuran dengan bahasa apa pun, terutama BJ. Sementara itu, sebagian yang lain menggunakan BS Jawareh sebagai talimarga di antara mereka. Akan tetapi, penjual yang menggunakan BS murni ini ketika berada di Pasar Sindang kadangkadang menggunakan bahasa Jawareh karena berhadapan dengan mitra tutur yang bukan dari etnis Sunda.

Penjual dari kelompok etnis atau orang Sunda tersebar dan bertempat tinggal di sepertiga daerah kabupaten Cirebon Selatan, terutama di daerah perbatasan kabupaten Kuningan dan Majalengka yang masyarakat tuturnya berBahasa Sunda. Kelompok dari etnis Sunda ini terbagi menjadi dua, yaitu kelompok etnis Sunda yang menggunakan BS murni dan kelompok etnis Sunda yang menggunakan BS campuran (Jawareh). Kelompok etnis Sunda yang menggunakan BS murni di dalam kehidupan sehari-hari adalah kelompok yang tinggal di daerah perbatasan dengan Kabupaten Majalengka dan Kuningan karena masyarakat tuturnya berBahasa Sunda. Sementara itu, kelompok etnis Sunda yang menggunakan BS Campuran adalah etnis Sunda yang bertempat tinggal di perbatasan daerah Jawa. Nama-nama daerah yang masyarakat tuturnya menggunakana BS murni, antara lain: Kuningan, Sigong, Sampih, Blender, Cipeujeuh Kulon, Sarijaya, Sindang Pancuran, Asem, Cikulak, Ciawi Asih, dan Cigobang. Sementara itu, nama-nama daerah masyarakat tuturnya menggunakan BS campuran (Jawareh), antara lain: Desa Lemahabang Kulon, Cipeujeuh Wetan, Tuk, Peradenan, Pande, Sindanglaut, Sigong, Karang Tengah, dan Susukan Lebak. 
Menurut Ayatrohaedi (1985), Penutur dari etnik Sunda ini didasarkan pada pandangan dan sikap hidup mereka sehari-hari. Mereka merasa merupakan bagian dari suku bangsa Sunda pada umumnya, lebih merasa dekat dengan tokoh Prabu Siliwangi daripada tokoh Sunan Gunung Jati, lebih menyukai bentuk-bentuk budaya Sunda, dan di dalam kehidupan sehari-hari mereka biasanya mempergunakan BS sebagai talimarga, meskipun mampu juga berbahasa Jawa. Dalam hal ini, kadangkadang mereka melakukan alih kode tergantung lawan tuturnya, meskipun tidak jarang juga melakukan campur kode. Berikut merupakan penjual yang menggunakan BS secara murni dalam interaksi jual beli di Pasar Sindang.

PT 14

\begin{tabular}{|c|c|}
\hline Setting & : kios buku \\
\hline $\mathrm{PN}$ & : Pr. 58 PM 1 (Ibu): 48;PM 2 (anak): 9 \\
\hline PM 1 & $\begin{array}{l}\text { : Nu mana deui sih, Neng? Ma enya hiji. } \\
\text { (Yang mana lagi sih, Dek? Masa Cuma satu. }\end{array}$ \\
\hline PM 2 & $\begin{array}{l}\text { : Nu koneng nu kawas ieu tapi nu gede. } \\
\text { (Yang kuning yang kaya ini tapi yang besar) }\end{array}$ \\
\hline PM 1 & $\begin{array}{l}\text { : Oh, teu aya nu ieuna } t a, B u ? \\
\text { (Oh, tidak ada yang ininya ya, Bu?) }\end{array}$ \\
\hline PN & $\begin{array}{l}\text { : Teu aya, muhun aya nu ageungna ieu, Neng, aya sapuluh, tilu lima. } \\
\text { (Tidak ada, iya ada yang besarnya ini, Dek, ada sepuluh, tiga lima) }\end{array}$ \\
\hline PM 1 & $\begin{array}{l}\text { : Iya bagus Nok, ulah ditempo dina gambarna. } \\
\text { (Iya bagus, Dek. Jangan dilihat dari gambarnya) }\end{array}$ \\
\hline PN & $\begin{array}{l}\text { : Leubeutna sae, Neng, berwarna. Tuh ieuna tinggal hiji wae tuh, kantun milih bae. } \\
\text { (Dalamnya bagus, Dek, berwarna. Tuh yang ini tinggal satu saja tuh, tinggal } \\
\text { pilih saja) }\end{array}$ \\
\hline
\end{tabular}

Peristiwa tutur di atas terjadi di kios buku. Semua partisipan berinteraksi menggunakan BS karena mereka berasal dari etnis Sunda. PN secara murni menggunakan BS tanpa ada campuran BJ sedikit pun, berbeda halnya dengan PM yang melakukan campur kode atau interferensi, berupa kata penegas BJ ta pada kalimat "oh, teu aya nu ieuna ta, Bu? Dan kata sapaan BJ Nok pada kalimat "iya bagus Nok, ulah ditempo dina gambarna".

Fenomena kebahasaan tersebut terjadi karena faktor daerah antara PN dan PM yang berbeda meskipun sama-sama berasal dari etnis Sunda, namun memiliki ragam bahasa (dialek) yang berbeda. Hal ini sebagaimana yang dikatakan oleh Alwi, dkk (2003: 3) bahwa ragam bahasa (language variation) secara umum dapat ditinjau dari dua hal. Yang pertama dari sudut pandang penuturnya, dan yang kedua menurut jenis pemakaiannya. Ragam bahasa yang ditinjau dari sudut pandang 
penutur dapat dirinci menurut patokan daerah, pendidikan dan sikap. Sementara itu, ragam bahasa menurut jenis pemakai dapat dibagi menjadi tiga, yaitu menurut pokok persoalan atau bidang, menurut sarana, dan yang mengalami percampuran atau interferensi. Dengan demikian, BS yang digunakan oleh PN dan PM dalam peristiwa tutur di atas menunjukkan adanya ragam bahasa yang dilihat baik dari penutur maupun sarana. Dari segi penutur, jelas berbeda karena faktor daerah yang mempengaruhi PN berasal dari daerah berBahasa Sunda murni, sedangkan pembeli berasal dari daerah berBahasa Sunda Campuran. Sementara itu, ragam bahasa menurut pemakaian, penjual melakukan interferensi BJ ke dalam BS seperti yang dijelaskan di atas.

Selanjutnya, berdasarkan data daftar penjual di Pasar Sindang, dapat dilihat bahwa penggunaan BS di Pasar Sindang dilakukan oleh penjual yang berjualan dengan jenis dagangan lokal, seperti sembako, mainan anak, meubel, warung nasi, pecah belah, sandal/sepatu, bakso, sayuran, kueh, kelapa, telor, daging sapi, anyaman, aksesoris, ayam, ikan asin, tempe/kerupuk, grabagan, daging ayam, bumbu, plastik, daging kambing, pakaian, masakan, (suruh, kinang, gambir), buahbuahan, ubi-ubian, perlengkapan sate, gilingan bumbu, cendol, minuman, pisang, sepuh, pecah belah, pakaian, sayuran, dan daging ayam.

Hal tersebut berhubungan dengan kehidupan sehari-hari penduduk etnis Sunda yang berlatar belakang pedesaan. Aktivitas di bidang pertanian masih mendominasi sebagian besar penduduk. Selain pertanian, di daerah-daerah beretnis Sunda juga terdapat industri pengerukan pasir seperti yang ada di Desa Kaligawe dan di Blok Dongkol Desa Asem yang berbatasan dengan Kecamatan Lemahabang. Pengguna hasil industri tersebut tersebar di wilayah Kabupaten Cirebon serta Kabupaten Kuningan. Selain itu, terdapat pula pengrajin bata merah yang di antaranya terdapat di Desa Curug dan sebelah timur Desa Susukan Agung.

Budaya etnis Sunda di daerah Cirebon Timur dan Selatan juga memiliki berbagai seni baik modern, tradisional atau pun yang berhubungan dengan keagamaan, terutama dalam pagelaran pentas seni ketika menjelang hari-hari besar umat Islam. Pagelaran seni tersebut, antara lain: organ tunggal, kesenian buraq, dan sholawatan. Sementara itu, hal-hal yang berhubungan dengan tradisi keagamaan yang unik dalam etnis Sunda, misalnya Ghiroh. Suatu tradisi yang sangat melekat di masyarakat etnis Sunda yang berkaitan dengan peringatan hari-hari besar Islam, seperti aktivitas Ramadhan, Syawal, dan Rayagung (Idul Adha). Sejumlah momen penting kerap diperingati pada hari-hari besar itu adalah Maulid Nabi Muhammad Saw, di bulan Rabiul Awwal dan munculnya penganan Cimplo di bulan Shafar. 
Cimplo merupakan penganan khas nan unik yang terbuat dari tepung terigu dengan proses pembuatan layaknya serabi. Masyarakat etnis Sunda umumnya mencocol cimplo ke dalam kuah khas berasal dari gula aren dan parutan kelapa. Cimplo menjadi unik dan khas karena jenis kuliner ini hanya dapat ditemui setahun sekali di bulan Shafar. Cimplo digunakan sebagai simbol untuk membuang bala yang konon banyak diturunkan Tuhan pada bulan tersebut. Tradisi membuang bala ini mengalami puncaknya pada hari Rabu terakhir di Bulan Shafar, yang dikenal dengan istilah Rebo Wakasan.

Menurut cerita warga setempat, pada pelaksanaan Rebo Wakasan akan turun 320.000 bala, musibah, ataupun bencana. Oleh karena itu, dikatakan bahwa pada hari itu merupakan hari yang paling berat sepanjang tahun. Pada hari Rebo Wakasan ini biasanya masyarakat membawa air dan berkumpul di Tajug (mushalla) untuk membacakan doa-doa tertentu. Tradisi Rebo Wakasan biasa dilakukan antara Maghrib dan Isya. Adapun air yang telah dibacakan doa-doa dari jamaah yang hadir kemudian dibawa pulang untuk diminum masing-masing jamaah dan keluarganya.

Berdasarkan sosio-kultural masyarakat etnis Sunda yang sudah diuraikan di atas, jelaslah jika ada relevansi yang erat mengapa jenis-jenis dagangan lokal seperti yang disebutkan sebelumnya menjadi jenis barang dagangan utama bagi PN yang berasal dari etnis Sunda. Latar belakang pedesaan yang kental akan tradisi-tradisi seni dan keagamaan itulah tampaknya, yang menjadi faktor utama bagi penduduk dari etnis Sunda yang menjajakkan jenis dagangan lokal. Hal ini juga berkenaan dengan hasil pertanian sebagai sumber mata pencaharian dan penghidupan mereka dan pelestarian tradisi budaya mereka yang khas dengan simbol-simbol berupa makanan, seperti cimplo, bubur sura dan lain-lain.

\section{Kesimpulan}

Berdasarkan hasil pembahasan, dapat disimpulkan bahwa BS yang digunakan dalam interaksi jual beli di Pasar Sindang Kabupaten Cirebon secara gramatikal tidak menunjukkan adanya perbedaan yang signifikan dengan Bahasa Sunda yang dipergunakan di daerah Sunda Priangan atau BSL, kecuali pada beberapa kosakata dan intonasi (lentong) tuturan. Ciri khusus dalam BSDJ terdapat pada penghilangan fonem vokal tertentu, seperti fonem /a/ dan / / Kosa kata dalam BSDJ juga mengalami gejala proses morfologi berupa afiksasi yang meliputi (prefiksasi, sufiksasi, infiksasi dan reduplikasi), nasalisasi dan pengulangan atau reduplikasi. Selain itu, kalimat aktif dalam BS menggunakan imbuhan $k u$ dan $n g$, nga- dan berakhiran $-k$ ön; dan pengulangan pada suku kata, sedangkan kalimat pasif BS 
dibagi menjadi dua bentuk, yaitu pasif berawalan $d i$ - dan $k a$ - yang ditandai dengan verba berafiks $d i-, d i-a n$, dan $d i-k e u n$. Adapun penggunaan BS dalam interaksi jual beli di Pasar Sindang Kabupaten Cirebon ada dua macam, yakni penggunaan BS murni dan penggunaan BS campuran BJ (Jawareh). Penggunaan BS baik murni atau pun campuran dilakukan oleh PN dan PM yang berasal dari etnis Sunda, sedangkan penutur yang menggunkan BS Jawareh berhadapan dengan mitra tutur yang bukan dari etnis Sunda.

\section{Ucapan Terima Kasih}

Saya mengucapkan banyak terima kasih kepada Prof. Dr. I Dewa Putu Wijana, S.U., M.A., selaku promotor, atas segala bimbingannya selama ini yang telah banyak memberikan masukan yang konstruktif demi penyelesaian artikel ini. Ucapan terima kasih saya juga haturkan kepada Dr. Fadlil Munawwar Manshur, M.S., selaku ko-promotor yang banyak meluangkan waktu dan pikirannya untuk berdiskusi tentang tema-tema kebahasaan.

\section{Daftar Pustaka}

Abdurrachman, Umsari, O.S, Zarkasih, Ruswandi. 1985. Struktur Bahasa Sunda Dialek Cirebon. Bandung: Pusat Pembinaan dan Pengembangan Bahasa Departemen Pendidikan dan Kebudayan.

Alwi, Hasan at.al. 1998. Tata Bahasa Baku Bahasa Indonesia. Jakarta: Balai Pustaka.

D.K. Ardiwinata, 1984. Tata Bahasa Sunda. Jakarta: Djambatan.

Ayatrohaedi, 1985. Bahasa Sunda di Daerah Cirebon. Jakarta: Balai Pustaka.

Cortesao, Armando, 1944. The Suma Oriental of Tome Pires, 2 jilid. London: The Hakluyt Society.

Coolsma, S. 1985. Tata Bahasa Sunda. Djakarta: Djambatan.

Edi Suhardi Ekajati, 1974. Sunan Gunung Jati dan Penyebaran Islam di Daerah Cirebon. Laporan Penataran Filologi (tidak diterbitkan).

I Wayan Jendra, 1991. Dasar-Dasar Sosiolinguistik. Denpasar-Bali: Ikayana.

Harimurti Kridalaksana, 1984. Kamus Linguistik. Jakarta: Gramedia.

M. Ramlan, 1976. "Penyusunan Tata Bahasa Struktural Bahasa Indonesia". Dalam Yus Rusyana dan Samsuri. Editor. Pedoman Penulisan Tata Bahasa Indonesia. Jakarta: Pusat Pembinaan dan Pengembangan Bahasa.

Henry Guntur Tarigan, 1977. Pengantar Sintaksis. Bandung: Jurusan Bahasa dan Sastra Indonesia FKSS-IKIP.

Verhaar, J.W.M. 1978. Pengantar Linguistik. Jilid 1. Yogyakarta: Gadjah Mada University Press. 